\title{
BMJ Open Defining the risk factors for acute, subacute and chronic cough: a cross- sectional study in a Finnish adult employee population
}

Anne M Lätti, ${ }^{1,2}$ Juha Pekkanen, ${ }^{3,4}$ Heikki O Koskela ${ }^{1,2}$

To cite: Lätti AM, Pekkanen J, Koskela HO. Defining the risk factors for acute, subacute and chronic cough: a crosssectional study in a Finnish adult employee population. BMJ Open 2018:8:e022950. doi:10.1136/ bmjopen-2018-022950

- Prepublication history and additional material for this paper are available online. To view these files, please visit the journal online (http://dx.doi. org/10.1136/bmjopen-2018022950).

Received 14 March 2018 Revised 16 May 2018 Accepted 19 June 2018

\section{Check for updates}

${ }^{1}$ Unit for Medicine and Clinical Research, Pulmonary Division, Kuopio University Hospital, Kuopio, Finland

${ }^{2}$ School of Medicine, Institute of Clinical Sciences, Faculty of Health Sciences, University of Eastern Finland, Kuopio, Finland ${ }^{3}$ Department of Public Health, University of Helsinki, Helsinki, Finland

${ }^{4}$ Environmental Health Unit, National Institute for Health and Welfare, Kuopio, Finland

Correspondence to

Dr Heikki 0 Koskela;

heikki.koskela@kuh.fi

\section{ABSTRACT}

Objectives Chronic cough is linked to various longstanding risk factors like asthma, chronic rhinitis and oesophageal reflux disease. On the contrary, acute and subacute cough are usually considered to be caused by acute respiratory infections. Little is known about the possible long-standing risk factors for acute and subacute cough. In this study, we have identified the long-standing risk factors for acute, subacute and chronic cough in order to identify the risk factors specifically associated with chronic cough.

Design A comprehensive 80-item questionnaire was sent via email to the participants.

Setting A community-based study to all public service employees of two towns in central Finland.

Participants There were 13980 employees, of them 3697 responded (26.4\%). Among the responders, there were 199 subjects with current daily acute cough (duration $<3$ weeks, prevalence $5.4 \%$ ), 126 subjects with current daily subacute cough (duration 3-8 weeks, prevalence $3.4 \%$ ) and 267 subjects with current daily chronic cough (duration $>8$ weeks, prevalence $7.2 \%$ ).

Primary outcome measures The risk factors that associated with each cough subtype. The subjects without any cough formed the reference group.

Results Several risk factors were associated with both short and long cough subtypes namely family history of chronic cough, moisture damage exposure and number of reported somatic symptoms. Furthermore, allergy was associated with acute and subacute cough. Current asthma and chronic rhinitis were associated with subacute and chronic cough. Oesophageal reflux disease and advanced age were associated with chronic cough. Conclusions The specific risk factors for chronic cough were oesophageal reflux disease and advanced age. Acute and subacute cough should not be regarded merely as symptoms of acute respiratory infections but possible manifestations of long-standing risk factors. A new risk factor for all cough types was family history of chronic cough.

\section{INTRODUCTION}

Cough is the most common disorder for which people seek medical advice from a doctor. ${ }^{1}$ It can be divided according to the duration: acute $<3$ weeks, subacute 3-8 weeks and
Strengths and limitations of this study

- The results are based on a large community-based sample of 3697 subjects.

- The study was from the very beginning planned to investigate cough risk factors and therefore included a comprehensive list of possible risk factors and detailed information about current cough.

- The study identified subjects with acute and subacute cough, in addition to chronic cough.

- Just $26.4 \%$ of the original population replied which may overestimate the cough prevalence figures.

- As all subjects were public service employees, low social classes and old persons are under-represented.

chronic $>8$ weeks. ${ }^{34}$ Chronic cough is nowadays considered a manifestation of cough hypersensitivity syndrome, a new concept to describe a condition with long-standing hypersensitivity of vagal afferent nerves or an alteration of the central processing of their input regardless of the background disorder of the cough. ${ }^{56}$ However, effective medical therapy for this neuronal hypersensitivity is currently lacking and the management of chronic cough still relies on effective identification and management of the background disorders and other risk factors. ${ }^{34}$ Therefore, better knowledge about chronic cough risk factors is essential.

Acute and subacute cough have usually been connected to acute respiratory tract infections. $^{78}$ On the contrary, chronic cough may be associated with long-standing risk factors like oesophageal reflux disease, asthma and rhinosinusitis. ${ }^{3}{ }^{4}$ Of note, the information about chronic cough risk factors has mainly been gained from selected populations treated in specialised cough clinics. To our knowledge, there are just three studies in which the risk factors for chronic cough have been investigated in community samples. ${ }^{9-11}$ 
Regurgitation, irritable bowel syndrome, smoking, declining social class and quality of life at baseline were the risk factors for chronic cough in a British study with 4003 middle-aged subjects. ${ }^{9}$ In a Danish study with 14669 subjects, the three top-ranked risk factors for chronic cough were bronchiectasis, asthma and occupational exposure to dust/fumes. ${ }^{10}$ Advanced age, smoking, chest X-ray abnormality, asthma and diabetes were the risk factors for chronic cough in a Korean study with 18071 participants. ${ }^{11}$ Though several risk factors for chronic cough have been identified, the long-standing risk factors for acute and subacute cough are less well known. Therefore, it is obscure whether the identified risk factors for chronic cough are specific for chronic cough only or, alternatively, might apply to all types of cough. In this study, we have identified the long-standing risk factors for acute, subacute and chronic cough in order to identify the risk factors specifically associated with chronic cough.

\section{MATERIALS AND METHODS Population}

This was a cross-sectional study among all public service employees of two middle-sized towns in central Finland (Kuopio and Jyväskylä, altogether 13980 employees). The average age of this population was 46.6 years with $79.2 \%$ females. Invitation to the study and the questionnaire was sent via email to the employees' email addresses in March to April 2017. Answers were collected via an electronic reply form. One reminding message was sent if a subject had not responded within 2 weeks. Permission to conduct the study was obtained from the town officials. The invitation mail to participate the study included detailed information about the study. The decision of the subject to reply was considered as an informed consent.

\section{Questionnaire}

The questions of the questionnaire have been mainly adopted from two previous, much used questionnaires. The first has been used in a Finnish annual postal survey entitled Health Behaviour and Health among the Finnish Adult Population. ${ }^{12}$ The second has been used in the Finnish National FINRISK Study. ${ }^{13}$ Therefore, the present questionnaire includes a lot of information not directly related to cough. The first part of the present questionnaire was filled in by all subjects. It included questions about the subject's household, pets, family incomes, occupation, physical activity, smoking history, alcohol consumption, general health-related questions, current medications, doctor's visits, sick leave days, recent (within 1 month) somatic symptoms (chest pain, arthralgia, back pain, toothache, leg oedema, varicose disorders, eczema, headache, constipation, oesophageal reflux, other gastrointestinal symptoms, sciatica, chronic rhinosinusitis and wheezing) as well as all disorders diagnosed by a doctor. In addition, there were cough-related questions which were created by the authors. The second part consisted of 23 detailed cough-related questions to be filled by subjects reporting of current cough (within 2weeks). Asthma-related, rhinosinusitis-related and reflux-related symptoms were asked by questions currently suggested for epidemiological studies. ${ }^{14-16}$ An electronic online supplementary file includes the blank copy of the questionnaire (Finnish).

\section{Definitions}

Current cough was divided to subtypes. Acute cough was defined as current (within 2 weeks) cough that had lasted for less than 3 weeks, subacute cough as current cough that had lasted for 3-8weeks, and chronic cough as current cough that had lasted for more than 8 weeks. To be included in the risk factor analysis, the subject's cough bout frequency had to be once a day or more often. Point prevalence refers to the prevalence of current (within 2 weeks) cough. The period prevalence of chronic cough indicated a positive answer to the question 'Have you suffered from episode(s) of prolonged (over 8 weeks) daily or almost daily cough within the last 12 months?'

Current asthma was present if all the following conditions were fulfilled: Presence of wheezing within 12 months, dyspnoea during wheezing and wheezing also without respiratory tract infection. This definition was selected among several possible definitions ${ }^{14}$ because it showed the closest association with the doctor's diagnosis of asthma in the present population $\left(\chi^{2}\right.$ test, $\left.\mathrm{p}<0.001\right)$. Chronic rhinosinusitis was present if there was either nasal blockage or nasal discharge (anterior or posterior nasal drip) and either facial pain/pressure or reduction/ loss of smell for more than 3 months. ${ }^{15}$ Oesophageal reflux disease was present if there was heartburn and/ or regurgitation on at least 1 day in a week during the last 3 months. ${ }^{16}$ Somatic symptom score was calculated by summing all reported somatic symptoms except cough, giving a value from 0 to 14 . Allergy was defined as a self-reported allergy to pollens, animals or food. Family history of chronic cough was defined as presence (now or in the past) of chronic (duration more than 8 weeks) cough in parents, sisters or brothers.

\section{Patient involvement}

Patients were not directly involved in the design, recruitment to or conduct of this study. The results will be disseminated to study participants utilising Kuopio town and Jyväskylä town intranet portals.

\section{Statistical analysis}

Descriptive data are presented as means and SDs. Bivariate associations were analysed using $\chi^{2}$ test and MannWhitney $\mathrm{U}$ test. The associations of the following variables with cough were analysed, based on plausible biological association with cough: age, gender, body mass index, years of education, family incomes, professional status, number of family members, pet ownership, moisture damage at home and at workplace, smoking history, alcohol consumption, level of daily physical exercise, family history of chronic cough, acetylsalicylic acid 
Table 1 The basic characteristics of the subjects

\begin{tabular}{|c|c|c|c|c|c|}
\hline Characteristic & $\begin{array}{l}\text { No current } \\
\text { cough } \\
\mathrm{n}=2716\end{array}$ & $\begin{array}{l}\text { Current acute } \\
\text { daily cough } \\
n=199\end{array}$ & $\begin{array}{l}\text { Current subacute } \\
\text { daily cough } \\
n=126\end{array}$ & $\begin{array}{l}\text { Current chronic } \\
\text { daily cough } \\
\mathrm{n}=267\end{array}$ & $\begin{array}{l}\text { Current infrequent } \\
\text { cough } \\
\mathrm{n}=365\end{array}$ \\
\hline Age, years & $47.6(10.8)$ & $47.3(10.7)$ & 47.7 (10.3) & $50.5(10.1)$ & $48.4(10.9)$ \\
\hline Female gender, \% & 82.2 & 87.9 & 86.5 & 83.1 & 81.0 \\
\hline Body mass index, $\mathrm{kg} / \mathrm{m}^{2}$ & $26.4(5.0)$ & $27.2(5.5)$ & $26.6(4.6)$ & $27.7(5.4)$ & $27.0(5.0)$ \\
\hline Pack-years among ever smokers & $6.2(8.8)$ & $6.5(9.0)$ & $7.0(9.9)$ & $8.6(10.8)$ & $6.1(8.6)$ \\
\hline $\begin{array}{l}\text { Family history of chronic cough, } \\
\%\end{array}$ & 31.4 & 41.3 & 51.6 & 49.6 & 47.7 \\
\hline Moisture damage exposure, \% & 23.2 & 30.7 & 32.5 & 36.7 & 32.3 \\
\hline Oesophageal reflux disease, \% & 10.8 & 8.5 & 15.9 & 24.3 & 18.4 \\
\hline Somatic symptom score & $2.4(1.9)$ & $3.0(1.9)$ & $3.4(2.4)$ & $4.0(2.5)$ & $3.5(2.3)$ \\
\hline
\end{tabular}

Figures are percentages or means and SDs.

intolerance, allergies, somatic symptom score, current asthma, chronic rhinosinusitis and oesophageal reflux disease. The variables showing at least suggestive $(p<0.1)$ association with the outcome variables in the bivariate analyses were included in the multivariate analyses using binary logistic regression analysis with backward directed stepwise process. When analysing the risk factors for the cough subtypes, each subtype was compared with the subjects without any current cough. A p value less than 0.05 was accepted as the level of statistical significance but results showing a suggestive association $(\mathrm{p}<0.1)$ are also presented. All analyses were performed using SPSS V.22 for the personal computer (SPSS).

\section{RESULTS}

The response rate was $26.4 \%$ (3697 subjects, mean age 47.8 (10.8) years, $82.6 \%$ females (table 1$)$ ). The proportion of missing values was less than $1 \%$ in all other questions except family income $(2.5 \%)$ and acetylsalicylic acid intolerance $(1.4 \%)$. There were 23 subjects who reported of current cough but did not define either the cough frequency or duration. They were excluded from the risk factor analyses.
The point prevalence of acute, subacute and chronic cough depended on the definition of bout frequency (table 2). With the bout frequency of at least once a day, the point prevalence of acute cough was $5.4 \%$, that of subacute cough $3.4 \%$ and that of chronic cough $7.2 \%$. The 12-month period prevalence of daily chronic cough was $13.9 \%$.

The following factors were associated with any current cough in the multivariate analysis: family history of chronic cough, moisture damage exposure, high somatic symptom score, allergy, current asthma, chronic rhinosinusitis and advanced age (table 3 ). The multivariate analyses about the cough subtypes are expressed in table 4 . There were factors which showed associations with both short and long cough subtypes as well as factors which were specific for certain cough subtypes.

\section{DISCUSSION}

In the present population consisting of working age, employed subjects with infrequent smoking, the risk factors for chronic cough were current asthma, chronic rhinosinusitis, oesophageal reflux disease, somatic symptom score, family history of chronic cough, moisture

Table 2 Point prevalence of current acute, subacute, chronic and any cough with different cough bout frequency criteria

\begin{tabular}{lllll}
\hline Bout frequency & Acute cough (\%) & Subacute cough (\%) & Chronic cough (\%) & All cough (\%) \\
\hline Any & 10.0 & 4.7 & 11.4 & 26.1 \\
Once a week or more often & 8.1 & 4.6 & 11.1 & 23.7 \\
2-3 days a week or more often & 7.3 & 4.3 & 10.0 & 21.6 \\
4-6 days a week or more often & 6.1 & 3.9 & 8.8 & 18.8 \\
Once a day or more often & 5.4 & 3.4 & 7.2 & 16.1 \\
\hline
\end{tabular}


Table 3 The adjusted ORs and 95\% Cls for various characteristics associated with any current daily cough ( $n=592)$, compared with subjects with no current cough $(n=2716)$

\begin{tabular}{ll}
\hline Characteristic & Adjusted ORs \\
\hline Family history of chronic cough & $1.57(1.30 \text { to } 1.91)^{\star \star \star}$ \\
\hline Moisture damage exposure & $1.46(1.19 \text { to } 1.79)^{\star \star *}$ \\
Somatic symptom score $\dagger$ & $1.12(1.07 \text { to } 1.18)^{\star \star \star}$ \\
Allergy & $1.23(0.97$ to 1.56$)$ \\
Current asthma & $2.29(1.75 \text { to } 3.00)^{\star \star \star}$ \\
Chronic rhinosinusitis & $2.19(1.71 \text { to } 2.80)^{\star \star *}$ \\
Age & $1.15(1.05 \text { to } 1.26)^{\star \star}$ \\
\hline
\end{tabular}

Binary logistic regression analysis with backward directed stepwise process. ORs are presented if $p<0.10$.

${ }^{\star \star} \mathrm{P}<0.01,{ }^{\star \star *} \mathrm{P}<0.001$.

†OR is expressed per one somatic symptom.

¥OR is expressed per one decade.

damage exposure and advanced age. It is notable that several of them were also risk factors for the shorter cough subtypes.

The three most constantly identified risk factors for chronic cough, namely chronic rhinosinusitis, asthma and oesophageal reflux disease ${ }^{34}$ were associated with chronic cough also in the present study. Of them, oesophageal reflux disease was the only disorder specifically associated with chronic cough whereas chronic rhinosinusitis and current asthma were also associated with subacute cough. This might be explained by the constant nature of oesophageal reflux. On the contrary, rhinosinusitis and asthma are often episodic, activated by seasonal allergens or upper respiratory tract infections. Advanced age was also specifically associated with chronic cough in the present study, corroborating previous reports. ${ }^{9-11} 17$ The reason for this association is obscure. To conclude, oesophageal reflux disease and advanced age seem to be specifically connected to chronic cough. However, it should be highlighted that current asthma and chronic rhinosinusitis increased the risk of chronic cough considerably more than either of them.

There are, to our knowledge, three previous community-based studies about chronic cough risk factors. Of the three most constantly identified risk factors for chronic cough (chronic rhinosinusitis, asthma and oesophageal reflux), only oesophageal reflux disease was associated with chronic cough in the British study. ${ }^{9}$ In the Danish study, both chronic rhinosinusitis, asthma and oesophageal reflux disease were associated. ${ }^{10}$ In the Korean study, only asthma was statistically significantly associated with chronic cough. ${ }^{11}$ The most important difference between the present and the previous community-based studies is the use of specific, internationally recommended symptom questions for all the three important background disorders in the present study. ${ }^{14-16}$ We did not want to rely on doctor's diagnoses or registry data. The previous British study included only oesophageal reflux-related symptom questions. ${ }^{9}$ The Danish study included only asthma-related symptom questions. ${ }^{10}$ The Korean study included only chronic rhinosinusitis-related symptom questions. ${ }^{11}$ Inevitably, without adequate symptom questions important background disorders are missed. Furthermore, to strengthen the risk factor analysis in the present study, it was concentrated on daily cough. The Danish and the Korean studies did not report the cough bout frequency at all while the British study accepted cough with a very low bout frequency of once weekly.

Subacute cough shared several common risk factors with chronic cough in the present study, especially current asthma and chronic rhinosinusitis. The same risk factors for subacute cough were recognised also in two previous Korean studies. ${ }^{711}$ In a previous Japanese study, asthma was common among patients with both

Table 4 The adjusted ORs and 95\% Cls for various characteristics in each cough subtype

\begin{tabular}{|c|c|c|c|}
\hline Characteristic & $\begin{array}{l}\text { Acute cough } \\
n=199\end{array}$ & $\begin{array}{l}\text { Subacute cough } \\
n=126\end{array}$ & $\begin{array}{l}\text { Chronic cough } \\
\mathrm{n}=267\end{array}$ \\
\hline Family history of chronic cough & $1.36(1.00 \text { to } 1.84)^{\star}$ & $1.97(1.36 \text { to } 2.86)^{\star \star \star}$ & $1.58(1.20 \text { to } 2.09)^{\star \star}$ \\
\hline Somatic symptom score $†$ & $1.13(1.06 \text { to } 1.21)^{\star \star *}$ & NS & $1.11(1.03 \text { to } 1.19)^{\star \star}$ \\
\hline Allergy & $1.50(1.06 \text { to } 2.14)^{\star}$ & $1.61(1.06 \text { to } 2.45)^{\star}$ & NS \\
\hline Oesophageal reflux disease & NS & NS & $1.50(1.03 \text { to } 2.18)^{\star}$ \\
\hline Age $\neq$ & NS & NS & $1.35(1.18 \text { to } 1.54)^{\star \star \star}$ \\
\hline
\end{tabular}

Each subtype is compared with the 2716 subjects without any current cough.

ORs are presented if $p<0.10$. Multivariate logistic regression analysis with backward directed stepwise process.

${ }^{*} \mathrm{P}<0.05,{ }^{\star \star} \mathrm{P}<0.01,{ }^{* \star \star} \mathrm{P}<0.001$.

†OR is expressed per one somatic symptom.

¥OR is expressed per one decade.

NS, not significant $(p>0.10)$. 
acute and subacute cough. ${ }^{8}$ Consistently with our study, oesophageal reflux disease was rare among both Korean and Japanese subjects with acute or subacute cough. In the present study, allergy was associated with acute and subacute cough but not with chronic cough. To conclude, these findings carry a clinically important message: allergy-related background disorders like chronic rhinosinusitis and asthma are not confined to chronic cough but should be taken into account also in subacute cough.

To our knowledge, this is the first time when family history of chronic cough is recognised as a risk factor for cough. It was associated with all cough subtypes. Thus, it is not a risk factor for cough prolongation but may represent a heritable tendency of an individual to react with cough to environmental triggers. For example, a subject with this tendency may cough in response to respiratory viral infection whereas a subject without this tendency might predominantly react with other symptoms like rhinitis, fever or headache. There is a paucity of studies about cough inheritance. It has been shown that SLCO1B1 genotype variants are associated with an increased risk of enalapril-induced cough. ${ }^{18}$ In addition, a Finnish twin study showed that throat clearing or coughing while talking may have an inherited component. ${ }^{19}$

The present study showed that an exposure to moisture damage is an independent risk factor for acute, subacute and chronic cough. This is in accordance with previous epidemiological studies and meta-analyses. ${ }^{20}$ This preventable and possibly treatable risk factor for cough may be under-recognised in current cough guidelines.

In the present study population, reporting of somatic symptoms tended to cluster in the same subjects. As a consequence, several odd associations were observed in the preliminary bivariate analysis of the present data (data not shown in the results section); for example, current cough was associated with arterial hypertension $(\mathrm{p}<0.001)$, hypercholesterolaemia $(\mathrm{p}=0.003)$, diabetes $(p=0.004)$, toothache $(p=0.019)$, leg oedema $(p<0.001)$, headache $(\mathrm{p}<0.001)$ etc. In fact, almost all doctor's diagnosed disorders and subject-reported symptoms showed bivariate associations with cough. We postulate that this phenomenon indicates somatisation, a condition characterised by multiple somatic symptoms and associated with depression and anxiety. It describes the interindividual variation in how subjects recognise and report symptoms. ${ }^{21}$ In the present study, somatisation was taken into account by the somatic symptom score and only characteristics with plausible biological association with cough were included in the final analyses. We acknowledge that the somatic symptom score is not a validated tool to investigate somatisation. However, we feel that somatisation is mandatory to take into account somehow when investigating disorders that are based on self-reported symptoms. For example, when adjusting the analyses for the somatic symptom score, all associations between female gender and cough disappeared. This is remarkable as cough is widely considered as a disorder of females. ${ }^{22}$
To our knowledge, the present study for the first time reported both the point prevalence and period prevalence of chronic cough. The point prevalence of cough is much more seldom reported than period prevalence, that is, prevalence of a disorder within a wide time frame, usually 12 months. The point prevalence has the advantage of being less subject to recall bias. Furthermore, considering that cough is frequently self-limiting, the measurement of point prevalence measure could be more appropriate for studying cough epidemiology. ${ }^{11}$ There are some previous studies which present the point prevalence of cough but none of them reported also the period prevalence. ${ }^{911} 17$ In the present population, the period prevalence of chronic cough was two times higher than its point prevalence demonstrating the striking contribution of the cough prevalence definitions on the prevalence estimates.

The cough prevalence estimates in the present study may have been inflated by the relatively low response rate. It is possible that subjects suffering of cough may have been more interested to respond than those without. However, the responders and non-responders did not differ with respect to age and sex distribution. Furthermore, the point prevalence of chronic cough in the present study $(11.1 \%)$ is almost same as that of the previous British study $(12.0 \%)$ when using the same bout frequency of at least once a week. ${ }^{9}$ The present study showed that the prevalence of various forms of cough strongly depends of the bout frequency. To be better able to compare cough prevalence figures in future studies, the bout frequency should be reported and preferably standardised. In addition, point prevalence should perhaps be reported instead of period prevalence.

The relatively low response rate had probably less effect on the risk factor analyses than on the prevalence estimates. However, there are also other limitations in the present study. The generalisability of the study may be limited since the study subjects were public service employees. Low social classes and old persons are therefore under-represented. This may partly explain the low smoking rate in the present population and the fact that smoking was not an independent risk factor for cough. Women are over-represented in the present population but women also seek medical advice due to cough more often than men. ${ }^{22}{ }^{23}$ All of the information used in the present analyses is based on self-reports in a cross-sectional design with the associated problems of biased reporting and lack of possibility to separate associations from causality.

The present study is, to our knowledge, the first community-based study about chronic cough risk factors that was from the very beginning planned for this purpose. Therefore, it has some unique credits. First, it included recommended symptom questions about chronic rhinosinusitis, current asthma and oesophageal reflux disease, together with a comprehensive list of other potential risk factors. Second, it included acute and subacute cough, besides chronic cough. Third, it provided detailed information 
about current cough including the bout frequency. To minimise the confounding effects of acute respiratory infections and pollens, the questionnaires were sent out in March and April. Thus, the responses would be expected to reflect nadir of seasonal cough.

In conclusion, the present study describes the risk factors for acute, subacute and chronic cough. Acute and subacute cough should not be regarded merely as symptoms of acute respiratory infections but possible manifestations of long standing, perhaps treatable cough risk factors. Specific chronic cough risk factors were oesophageal reflux disease and advanced age. A new important risk factor for all cough types was family history of chronic cough.

Acknowledgements We thank Seppo Hartikainen for his assistance in creating the electronic questionnaire.

Contributors AML made substantial contributions to the conception and design of the work, the acquisition, analysis and interpretation of data for the work, and drafting the work. She mainly wrote the manuscript. She made the final approval of the version to be published and an agreement to be accountable for all aspects of the work in ensuring that questions related to the accuracy or integrity of any part of the work are appropriately investigated and resolved. JP made substantial contributions to the conception and design of the work and interpretation of data for the work, and drafting the work. He made the final approval of the version to be published and an agreement to be accountable for all aspects of the work in ensuring that questions related to the accuracy or integrity of any part of the work are appropriately investigated and resolved. HOK made substantial contributions to the conception and design of the work, the acquisition, analysis and interpretation of data for the work, and drafting the work. He made the final approval of the version to be published and an agreement to be accountable for all aspects of the work in ensuring that questions related to the accuracy or integrity of any part of the work are appropriately investigated and resolved.

Funding The study was funded by grants from Kuopion Hengityssäätio and Hengityssairauksien Tutkimussäätiö foundations.

Competing interests AML reports grants from Kuopion Hengityssäätiö Foundation, grants from Hengityssairauksien Tutkimussäätiö, during the conduct of the study; personal fees from Orion, Boehringer-Ingelheim, Roche to visit international scientific meetings, outside the submitted work. HOK reports grants from Kuopion Hengityssäätiö Foundation, grants from Hengityssairauksien Tutkimussäätiö, during the conduct of the study; personal fees from Mundipharma, Orion Pharma, Oy, Eli Lilly Finland, Boehringer Ingelheim Finland as payments for giving scientific lectures in gatherings organised by medical companies, personal fees from Takeda Leiras, Boehringer Ingelheim and Mundipharma to visit international scientific meetings, other from owning shares of Orion Pharma worth $€ 25000$, outside the submitted work.

\section{Patient consent Not required.}

Ethics approval The study was approved by the Ethics Committee of Kuopio University Hospital (289/2015).

Provenance and peer review Not commissioned; externally peer reviewed. Data sharing statement There are no additional unpublished data.

Open access This is an open access article distributed in accordance with the Creative Commons Attribution Non Commercial (CC BY-NC 4.0) license, which permits others to distribute, remix, adapt, build upon this work non-commercially, and license their derivative works on different terms, provided the original work is properly cited and the use is non-commercial. See: http://creativecommons.org/ licenses/by-nc/4.0/

(C) Article author(s) (or their employer(s) unless otherwise stated in the text of the article) 2018. All rights reserved. No commercial use is permitted unless otherwise expressly granted.

\section{REFERENCES}

1. Wändell $P$, Carlsson AC, Wettermark B, et al. Most common diseases diagnosed in primary care in Stockholm, Sweden, in 2011. Fam Pract 2013;30:506-13.

2. Centers for disease control and prevention, USA. National Ambulatory Medical Care Survey: 2010 Summary Tables. 2014 http:// www.cdc.gov/nchs/data/ahcd/namcs_summary/2010_namcs_web_ tables.pdf.

3. Irwin RS, Baumann MH, Bolser DC, et al. Diagnosis and management of cough executive summary: ACCP evidence-based clinical practice guidelines. Chest 2006;129:23S.

4. Morice $\mathrm{AH}$, et al. Recommendations for the management of cough in adults. Thorax 2006;61(suppl_1): i1-i24.

5. Chung KF. Chronic 'cough hypersensitivity syndrome': a more precise label for chronic cough. Pulm Pharmacol Ther 2011;24:267-71.

6. Morice AH, Faruqi S, Wright CE, et al. Cough hypersensitivity syndrome: a distinct clinical entity. Lung 2011;189:73-9.

7. Kwon NH, Oh MJ, Min TH, et al. Causes and clinical features of subacute cough. Chest 2006;129:1142-7.

8. Yamasaki A, Hanaki K, Tomita K, et al. Cough and asthma diagnosis: physicians' diagnosis and treatment of patients complaining of acute, subacute and chronic cough in rural areas of Japan. Int $J$ Gen Med 2010;3:101-7

9. Ford AC, Forman D, Moayyedi P, et al. Cough in the community: a cross sectional survey and the relationship to gastrointestinal symptoms. Thorax 2006;61:975-9.

10. Çolak Y, Nordestgaard BG, Laursen LC, et al. Risk Factors for Chronic Cough Among 14,669 Individuals From the General Population. Chest 2017;152:563-73.

11. Kang MG, Song WJ, Kim HJ, et al. Point prevalence and epidemiological characteristics of chronic cough in the general adult population: The Korean National Health and Nutrition Examination Survey 2010-2012. Medicine 2017;96:e6486.

12. National Institute for Health and Welfare. Health Behaviour and Health among the Finnish Adult Population. https://thl.fi/en/ tutkimus-ja-kehittaminen/tutkimukset-ja-hankkeet/aikuistenterveys-hyvinvointi-ja-palvelututkimus-ath/aiemmat-tutkimukset/ suomalaisen-aikuisvaeston-terveyskayttaytyminen-ja-terveys-avtk (accessed May 2018).

13. National Institute for Health and Welfare. The National FINRISK Study. https://thl.fi/en/web/thlfi-en/research-and-expertwork/ population-studies/the-national-finrisk-study (access May 2018).

14. Sá-Sousa A, Jacinto T, Azevedo LF, et al. Operational definitions of asthma in recent epidemiological studies are inconsistent. Clin Trans/ Allergy 2014;4:24.

15. Fokkens WJ, Lund VJ, Mullol J, et al. EPOS 2012: European position paper on rhinosinusitis and nasal polyps 2012. A summary for otorhinolaryngologists. Rhinology 2012;50:1-298.

16. El-Serag HB, Sweet S, Winchester CC, et al. Update on the epidemiology of gastro-oesophageal reflux disease: a systematic review. Gut 2014;63:871-80.

17. Fujimura M. Frequency of persistent cough and trends in seeking medical care and treatment-results of an internet survey. Allergol Int 2012;61:573-81.

18. Luo JQ, He FZ, Wang ZM, et al. SLCO1B1 Variants and Angiotensin Converting Enzyme Inhibitor (Enalapril)-Induced Cough: a Pharmacogenetic Study. Sci Rep 2015;5:17253.

19. Nybacka I, Simberg S, Santtila P, et al. Genetic and environmental effects on vocal symptoms and their intercorrelations. J Speech Lang Hear Res 2012;55:541-53.

20. Mendell MJ, Mirer AG, Cheung K, et al. Respiratory and allergic health effects of dampness, mold, and dampness-related agents: a review of the epidemiologic evidence. Environ Health Perspect 2011;119:748-56.

21. Croicu C, Chwastiak L, Katon W. Approach to the patient with multiple somatic symptoms. Med Clin North Am 2014;98:1079-95.

22. Kavalcikova-Bogdanova N, Buday T, Plevkova J, et al. Chronic Cough as a Female Gender Issue. Adv Exp Med Biol 2016;905:69-78.

23. Morice $A H$, Jakes $A D$, Faruqi $S$, et al. A worldwide survey of chronic cough: a manifestation of enhanced somatosensory response. Eur Respir J 2014;44:1149-55. 